\title{
FAKTOR YANG MEMPENGARUHI PROFITABILITAS PERBANKAN SYARIAH DI INDONESIA
}

\section{FACTORS THAT AFFECTING ISLAMIC BANKING PROFITABILITY IN INDONESIA}

\author{
Tamimah $^{1}$
}

${ }^{1}$ Master Islamic Economic Science, Faculty of Economics and Business, Universitas Airlangga, Surabaya Jl. Airlangga No.4 - 6, Airlangga, Kec. Gubeng, Kota SBY, Jawa Timur 60115. email: tamimah-2018@pasca.unair.ac.id

\begin{abstract}
Islamic Banking in Indonesia has a positive trend, even this institution must have a strong foundation to maintain its ability to be able to compete with other Islamic banks to increase expected profitability. This success can be seen from many factors. One of them is based on the performance of Islamic banking itself. This study aims to analyze NPF, FDR, CAR, and BOPO as independent variables and ROA as the dependent variable. This type of research uses quantitative data using panel data since the period 2010-2017 using the random effects method. The results show that the variable NPF, CAR, and BOPO significantly influence ROA, while FDR does not oppose ROA
\end{abstract}

Kata Kunci: Profitabilitas, NPF, FDR, CAR, BOPO

\begin{abstract}
ABSTRAK
Perbankan syariah di Indonesia telah menunjukkan trennya yang positif, bahkan lembaga tersebut harus memiliki pondasi yang kuat untuk mempertahankan kemampuannya agar dapat bersaing dengan perbankan syariah lainnya untuk mendapatkan profitabilitas yang diharapkan. Kesuksesan tersebut dilihat dari banyak faktor salah satunya berdasarkan performan perbankan syariah itu sendiri. Penelitian ini bertujuan untuk menganalisis NPF, FDR, CAR, dan BOPO sebagai variabel independen dan ROA sebagai variabel dependen. Jenis penelitian yang digunakan menggunakan data kuantitatif dengan menggunakan data panel sejak periode 2010-2017 dengan menggunakan metode random effect. Hasil menunjukkan vahwa variabel NPF, CAR, dan BOPO berpengaruh signifikan terhadap ROA, sedangkan FDR tidak berpengaruh terhadap ROA.
\end{abstract}

Kata kunci: Profitabilitas, NPF, FDR, CAR BOPO

Tamimah. 2020. Analisis Faktor-Faktor yang Mempengaruhi Profitabilitas Perbankan Syariah di Indonesia . Jurnal Syarikah 6(1): 104-113 .

\section{PENDAHULUAN}

Krisis yang terjadi pada tahun 1997 memberikan penyadaran kepada semua pihak bahwa sistem perbankan konvensional bukan satu-satunya sistem yang dapat diandalkan (Amelia, 2015). Masalah krisis tersebut mampu merubah perekonomian Indonesia menjadi terpuruk. Oleh karena itu sektor perbankan 
membutuhkan sistem yang dapat memberikan solusi terhadap masalah yang ditimbulkan dari penerapan sistem bunga yang terdapat dalam perbankan tersebut (Wibowo, 2013).

Bank syariah merupakan badan usaha yang beroperasi menghimpun dana dari masyarakat dalam bentuk simpanan dan menyalurkannya kepada masyarakat menggunakan prinsip bagi hasil (Hakiim \& Rafsanjani, 2016). Hal ini yang menjadi keunggulan bagi perbankan syariah sehingga dapat bertahan menghadapi krisis yang sedang berdampak terhadap perekonomian secara global. Pertumbuhan perbankan yang berkaitan dengan ekonomi sektor riil mampu menjadi solusi dalam penderitaan negative spread yang dialami perbankan konvensional (Harianto , 2017). Sejak saat itu bank syariah menjadi alternatif bagi bank konvensional dalam mengembangkan ekonomi Indonesia.

Tabel 1. Perkembangan Kelembagaan dan Kinerja Perbankan Syariah Indonesia Tahun 2010-2017

\begin{tabular}{rrrrrrrrr}
\hline Indikator & 2010 & 2011 & 2012 & 2013 & 2014 & 2015 & 2016 & 2017 \\
\hline BUS & 11 & 11 & 11 & 11 & 12 & 12 & 13 & 13 \\
UUS & 23 & 24 & 24 & 23 & 22 & 22 & 21 & 21 \\
Jumlahkantor & 1.477 & 1.737 & 2.264 & 2.588 & 2.483 & 2.301 & 2.201 & 2.728 \\
\hline ASET (millar Rp) & 97.519 & 145.467 & 195.018 & 242.276 & 272.343 & 296.262 & 356.504 & 424.181 \\
DPK (miliar Rp) & 76.036 & 115.415 & 147.512 & 183.534 & 217.858 & 231.175 & 279.335 & 334.719 \\
PYD (miliar Rp) & 68.181 & 102.655 & 147.505 & 184.122 & 199.330 & 212.996 & 248.007 & 285.695 \\
\hline
\end{tabular}

Banyak tantangan yang dihadapi oleh perbankan syariah pada awal pembentukannya, karena masih banyak masyarakat yang belum memahami dan percaya tentang konsep yang diterapkan oleh perbankan syariah (Sukamana \& Febriyanti, 2016). Disisi lain kinerja asset yang dimiliki oleh perbankan syariah masih sangat minim. Meskipun dari perkembangannya, perbankan syariah menunjukkan tren yang poisitif sehingga hal ini perlu di tingkatkan. Untuk menumbuhkan asset perbankan syariah, diperlukannya kinerja keuangan yang baik untuk mendorong perkembangannya.

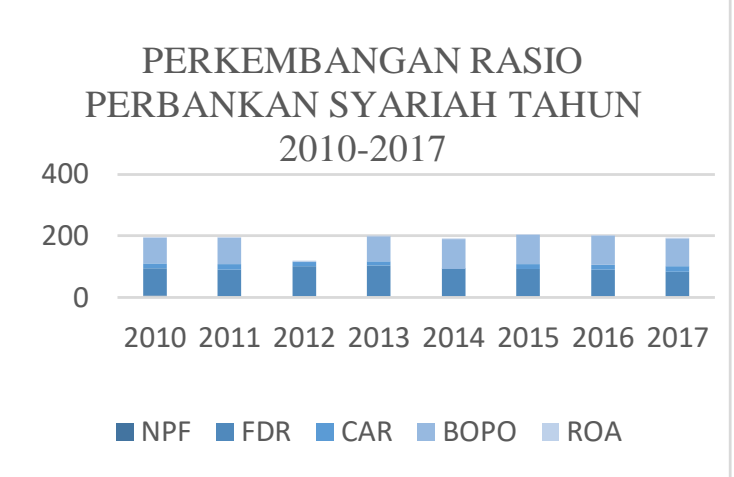

Gambar 1. Perkembangan Rasio Perbankan Syariah Tahun 2010-2017

Deskripsi pada gambar 1 menunjukkan bagaimana kondisi kinerja keuangan perbankan syariah di Indonesia. Kinerja keuangan perbankan syariah mengalami fluktuatif setiap tahunnya dapat dinilai oleh beberapa indikator, salah satu indikator utama yang digunakan sebagai dasar penilaian adalah laporan keuangan bank. Berdasarkan laporan keuangan akan dihitung sejumlah rasio yang biasa digunakan sebagai dasar penilaian bank (Amelia, 2015). Rasio yang digunakan untuk melihat kinerja keuangan menggunakan Non Performing Financing (NPF), Financing Deposit Ratio (FDR), Capital Adequacy ratio (CAR), Biaya operasional terhadap pendapatan operasional (BOPO) sehingga dari rasio tersebut dapat diketahui rasio apa saja yang dapat berpengaruhi profitabilitas perbankan syariah dengan menggunakan rasio Return On Asset (ROA).

Terdapat berbagai penelitian yang dilakukan oleh peneliti sebelumnya untuk mengetahui kinerja perbankan syariah (Nurismalatri, 2019: Purnamasari \& Ariyanto, 2016: Yusuf \& Surjaatmadja, 2018: Artha \& Mulyana, 2018). Namun dalam penelitian sebelumnya menggunakan dasar dengan banyak profitabilitas yang digunakan sehingga pembahasannya menggunakan banyak indikator dan menyebabkan penelitian yang digunakan tidak menspesifikasi. Namun peneliti membahas dari profitabilitas yang dipengaruhi oleh performan dan fokus terhadap ROA yang dijadikan sebagai indikator profitabilitas sehingga dari hal ini dapat menjelaskan secara utuh apa saja 
faktor-faktor yang mempengaruhi performnace perbankan syariah sehingga dari hal ini dapat memaksimalkan kinerja yang telah dimiliki.

\section{MATERI DAN METODE}

Variabel penelitian yang digunakan dalam mengukur kinerja keuangan perbankan syariah dalam penelitian ini menggunakan Non Performing Financing (NPF), Financing Deposit Ratio (FDR), Capital Adequacy ratio (CAR), Biaya operasional terhadap pendapatan operasional (BOPO) dan profitabilitas perbankan syariah yang digunakan menggunakan Return On Asset (ROA).

NPF dan Profitabilitas Perbankan Syariah NPF Merupakan kredit ataupun pembiayaan bermasalah yang dilakukan oleh debitur karena tidak dapat memenuhi pembayaran pinjaman dalam jangka waktu yang telah disepakati pada saat perjanjian (Syaichu \& Wibowo, 2013). Resiko yang ditimbulkan dari hal ini adalah ketika perbankan tidak dapat memulihkan pengembalian peminjaman yang dilakukan oleh debitur (Yusuf \& Surjaatmadja, 2018). Faktor yang menyebabkan terjadinya pembiayaan macet disebabkan oleh faktor eksternal diluar kemampuan debitur dalam membayar dan disisi lain disebabkan oleh faktor kesengajaan yang dilakukan oleh debitur (Husaeni, Jamil, \& Riadi, 2013). Oleh karena itu aktivitas yang dilakukan oleh debitur akan menghasilkan risiko pembiayaan (NPF) yang diberikan oleh perbankan. Jika jumlah pembiayaan macet tinggi maka akan berdampak terhadap profitabilitas perbankan, sehingga profitabilitas perbankan akan menurun. Hal ini menunjukkan bahwa perbankan syariah tidak memiliki kemampuan dalam mengelola pembiayaan secara professional dan berdampak terhadap profitabilitas perbankan syariah (ROA) menurun (Mawadah, 2015). Sehingga NPF memiliki pengaruh terhadap profitabilitas perbankan syariah. (Sitompul \& Nasution, 2019: Amzal , 2016: Suartini, Sulistyo, \& Indrianti, 2018).
Namun terdapat penelitian yang menunjukkan bahwa NPF tidak memiliki pengaruh terhadap ROA (Sriyana, 2015: Jatmiko, Srikalimah, \& Fitryanto, 2017)

FDR dan profitabilitas perbankan syariah. Likuditas mengacu terhadap kemampuan perbankan dalam memenuhi kewajibannya terhadap pihak ketiga baik dari individu mapun suatu entitas bisnis (Kusa \& Berhanu, 2013). Likuditas perusahaan berkaitan dengan kemampuan sebuah perusahaan mengganti asset menjadi uang tunai (Broome, Moore, \& Winston, 2009). Salah satu untuk mengukur likuiditas perbankan adalah menggunakan FDR (Wahyuningsih , Oemar, \& Suprijanto, 2015). FDR adalah perbandingan antara pembiayaan yang diberikan oleh bank dengan dana pihak ketiga yang berhasil digunakan oleh bank (Suhartatik \& Kusumaningtias, 2013). Jika bank dapat menyalurkan seluruh dana yang dihimpun memang akan sangat menguntungkan, namun hal ini terkiat dengan resiko apabila sewaktu-waktu pemilik dana tidak dapat mengembalikan dana yang dipinjamnya. Secara lebih rinci FDR dapat di jelaskan sebagai rasio antara seluruh jumlah kredit yang diberikan bank dengan dana yang diterima bank (Almunawwaroh \& Marliana, 2018). Jika nilai FDR menunjukkan persentasenya terlalu tinggi maka akan berrisiko terhadap likuiditas perbankan, namun sebaliknya jika likuiditas terlalu rendah maka perbankan dianggap tidak efektif dalam mengumpulkan dan menyalurkan dana yang diperoleh dari debitur sehingga mempengaruhi laba yang akan diperoleh. Presentase FDR yang ditetapkan oleh Bank Indonesia adalah 110\%. Sehingga semakin tinggi distribusi dana yang disalurkan melalui pembiayaan, resiko pembiayaan bermasalah juga akan meningkat, sehingga juga akan menaikkan NPF (Yasin, 2018). Sehingga semakin tinggi FDR maka profitabilitas juga akan semakin tinggi. Sehingga dari hal ini menujukkan bahwa FDR berpengaruh terhadap ROA (Wardana \& Widyarti, 2015: Amelia, 2015: (Yusuf \& Surjaatmadja, Analysis of Financial 
Performance on Profitability with Non Performance Financing as Variable Moderation (Study at Sharia Commercial Bank in Indonesia Period 2012-2016), 2018). Namun terdapat penelitian yang menunjukkan bahwa tidak mendukung terhadap penelitian tersebut (Said \& Ali, 2016).

CAR dan profitabilitas perbankan syariah CAR digunakan untuk menilai kemampuan bank untuk menanggung resiko yang akan terjadi. Apabila CAR dalam suatu perbankan tinggi, menunjukkan bahwa perbankan tersebut memiliki ekuitas yang lebih besar untuk menutupi resiko yang dapat mempengaruhi jumlah modal dalam perbankan (Winarso \& Salim, 2017). Modal bank juga berfungsi agar deposan yang menyimpan uangnya di bank tidak merasa terbebani oleh resiko macetnya dana ketika dibutuhkan untuk kepentingan yang tak terduga oleh pihak deposan (Artha \& Mulyana, 2018). Rasio kecukupan modal didasarkan pada prinsip bahwa setiap investasi yang mengandung resiko harus disediakan modalnya terhadap total investasi dalam presentase tertentu (Riadi, 2018). Bank Indonesia menetapkan CAR yang harus dimiliki oleh perbankan adalah 8\%. Jika perbankan mampu memenuhi persyaratan yang telah ditetapkan oleh Bank Indonesia, maka perbankan mampu menjaga likuiditas dan akan memperoleh profitabilitas (Abdillah, Hosen, \& Muhari, 2016). Dalam melihat CAR dalam perbankan syariah, hal pertama yang dipertimbangakan adalah bahwa aktiva di perbankan syariah didanai oleh modal sendiri dan didanai oleh bagi hasil (Hakiim \& Rafsanjani, 2016). CAR dihubungkan dengan tingkat resiko bank. Semakin tinggi rasio kecukupan modal, semakin kuat kemampuan bank tersebut untuk menanggung risiko dari setiap kredit/aktiva produktif yang berisiko, dan bank tersebut mampu membiayai operasi bank sehingga akan memberikan kontribusi yang cukup besar terhadap profitabilitas (Purnamasari \& Ariyanto, 2016). Hal ini menunjukkan bahwa CAR berpengaruh terhadap ROA
(Yusuf \& Surjaatmadja, Analysis of Financial Performance on Profitability with Non Performance Financing as Variable Moderation (Study at Sharia Commercial Bank in Indonesia Period 2012-2016) , 2018: Amelia, 2015: Hakiim \& Rafsanjani, 2016: Farandy, Suwito, \& Dabutar, 2017). Namun terdapat penelitian yang menunjukkan bahwa CAR tidak berpengaruh terhadap ROA, hal ini sesuai dengan penelitian (Amelia, 2015)

BOPO dan profitabilitas perbankan syariah merupakan perbandingan antara biaya operasional dengan pendapatan operasional dalam mengukur tingkat efisiensi dan kemampuan bank dalam melakukan kegiatan operasionalnya (Hakiim \& Rafsanjani, 2016). BOPO digunakan untuk mengukur efisiensi operasional bank. Efisiensi dalam perbankan sangat dibutuhkan, perbankan harus menempati tingkat BOPO yang paling rendah sehinga perbankan tersebut akan memperoleh laba. Jika tingkat BOPO dalam perbankan berada pada level paling tinggi, hal itu menunjukkan bahwa perbankan belum mampu mengelola biaya operasional maka laba akan menurun (Nahar \& Prawoto, 2017). Kriteria BOPO dalam perbankan tediri dari tingkat efisiensi diatas 96\% yang menunjukkan sangat rendah, $80 \%$ menunjukkan sangat bagus, $80 \%$ dan 95\% pada tingkat efisiensi cukup baik. Hal ini menunjukkan bahwa semakin tinggi tingkat beban pembiayaan bank, semakin kecil keuntungan yang didapat oleh perbankan. Beban biaya operasional yang tinggi dari bank yang dikenakan pada pendapatan yang berasal dari alokasi pembiayaan. Sehingga tinggi beban pinjaman akan mengurangi modal dan keuntungan yang dimiliki oleh perbankan (Said \& Ali, 2016). Sehingga hal ini menunjukkan bahwa BOPO berpengaruh terhadap ROA (Yusuf \& Surjaatmadja, Analysis of Financial Performance on Profitability with Non Performance Financing as Variable Moderation (Study at Sharia Commercial Bank in Indonesia Period 2012-2016) , 2018). Namun 
terdapat penelitian yang menunjukkan bahwa BOPO tidak berpengaruh terhadap ROA, hal ini sesuai dengan penelitian (Amelia, 2015).

\section{Profitabilitas Perbankan Syariah}

Profitabilitas adalah kemampuan perusahaan untuk memperoleh laba dan kaitannya dengan penjualan, total aset, dan modal. Sehingga investor diperlukan untuk menganalisis tingkat profitabilitas sebuah perbankan (Yusuf \& Surjaatmadja, 2018). Dalam penelitian ini menggunakan rasio return on asset (ROA) yang berfungsi untuk mengukur efektivitas perusahaan dalam menghasilkan laba dengan memanfaatkan aset yang dimiliki. Semakin besar ROA yang dimiliki oleh perusahaan, semakin efisien penggunaan asset sehingga dapat memperbesar keuantungan. Apabila perbankan syariah memiliki kentungan besar, akan menarik minat investor mengingat tingkat pengembalian yang tinggi dari perushaan tersebut. Penelitian ini hanya fokus pada pengunaan ROA, karena peneliti bertujuan untuk mengetahui sejauh mana kemampuan perbankan syariah dalam menghasilkan laba dari aset yang sebagian besar dananya berasal dari dana publik.

Jenis penelitian ini menggunakan penelitian kuantitatif. Data diperolah dari tahun 2010-2017. Objek penelitiannya adalah terdiri dari 6 perbankan syariah yang terdiri dari BCA syariah, BNI syariah, Bank Mega Syariah, Bank Muamalah, Maybank Syariah, dan BRI syariah. Variabel independen yang digunakan dalam penelitian ini didapatkan dari penelitian terdahulu yang telah terbukti mampu menjelaskan pengaruhnya terhadap kinerja bank. Adapun variabel independen tersebut adalah Capital Adequacy Ratio (CAR), Non Performing Financing (NPF), Financing Deposit Ratio (FDR), dan Biaya Operasional terhadap Pendapatan Operasional (BOPO). Sedangkan variabel dependen adalah profitabilitas bank yang diproksikan dalam rasio Return On Assets (ROA). Untuk melihat hubungan antar variabel baik dalam silang tempat dan runtut waktu, maka digunakan model regresi panel data. Metode analisis tersebut dapat dirumuskan sebagai berikut:

$\mathrm{ROA}_{\text {it }}=\beta_{0}+\beta_{1} \mathrm{NPF}_{\mathrm{it}}+\beta_{2} \mathrm{FDR}_{\mathrm{it}}+\beta_{3} \mathrm{CAR}_{\mathrm{it}}+$ $\beta_{4} \mathrm{BOPO}_{\text {it }}+\mathrm{e}_{\mathrm{it}}$

$\mathrm{Y}_{\mathrm{it}}=\mathrm{ROA}$

$\mathrm{B}=$ Konstanta

$\mathrm{i}=$ Bank umum syariah

$\mathrm{t}=$ Periode waktu

$\mathrm{X}_{1}=$ Non Performing Financing (NPF)

$\mathrm{X}_{2}=$ Financing Deposit Ratio (FDR)

$\mathrm{X}_{3}=$ Capital Adequacy ratio (CAR)

$\mathrm{X}_{4}=$ Biaya operasional terhadap pendapatan operasional (BOPO)

\section{HASIL DAN PEMBAHASAN}

Pengujian model penelitian menggunakan analisis data panel, dalam penelitian ini telah dilakukan uji estimasi menggunakan Uji Hausman. Hasilnya penelitian ini menggunakan model Random Effect.

Tabel 2. Perkembangan ROA Perbankan Syariah Tahun 2010-2017

\begin{tabular}{ccccccccc}
\hline $\begin{array}{c}\text { Perbankan } \\
\text { Syariah }\end{array}$ & 2010 & 2011 & 2012 & 2013 & 2014 & 2015 & 2016 & 2017 \\
\hline $\begin{array}{c}\text { BCA } \\
\text { Syariah }\end{array}$ & 1.3 & 0.9 & 0.8 & 1 & 0.8 & 1 & 1.1 & 1.2 \\
\hline $\begin{array}{c}\text { BNI } \\
\text { Syariah }\end{array}$ & 0.61 & 1.29 & 1.84 & 1.37 & 1.27 & 1.43 & 1.44 & 1.31 \\
\hline $\begin{array}{c}\text { Bank Mega } \\
\text { Syariah }\end{array}$ & 1.9 & 1.58 & 3.81 & 2.33 & 0.29 & 0.3 & 2.63 & 1.56 \\
\hline $\begin{array}{c}\text { Bank } \\
\text { Muamalah }\end{array}$ & 1.36 & 1.13 & 0.2 & 0.5 & 0.17 & 0.2 & 0.22 & 0.11 \\
\hline $\begin{array}{c}\text { Maybank } \\
\text { Syariah }\end{array}$ & 4.48 & 3.57 & 2.88 & 2.87 & 3.61 & 20.13 & 9.51 & 5.5 \\
\hline $\begin{array}{c}\text { BRI } \\
\text { Syariah }\end{array}$ & 0.35 & 0.2 & 1.19 & 1.15 & 0.08 & 0.76 & 0.95 & 0.51 \\
\hline & & & & & & & \\
\hline
\end{tabular}

Sumber: (OJK, 2018)

Perkembangan ROA perbankan syariah di Indonesia sangat berfluktuatif. Dalam tujuh tahun terakhir ROA perbankan syariah terendah terdiri dari Bank Muamalah yang berkisar antara 0.2\%-1.36. Maybank syariah menunjukkan profitabilitas tertinggi berkisar di angka 
20.13\%. Namun profitabilitas yang diperoleh perbankan syariah tidak sebanding dengan profitabilitas yang diperoleh perbankan konvensional. Oleh sebab itu perlunya perbankan syariah di Indonesia meningkatkan kinerjanya sehingga dapat memperoleh kepercayaan publik dan memicu investor beralih dari perbankan syariah kepada perbankan konvensional sehingga dapat menumbuhkan perbankan syariah di Indonesia.

Berdasarkan hasil uji statistik deskriptif dapat dilihat bahwa variabel FDR, CAR, BOPO memiliki mean yang lebih besar dari standar deviasi yang diartikan bahwa data dalam variabel tersebut berkelompok atau tidak bervariasi (Nurismalatri, 2019). Sedangkan NPF dan ROA memiliki mean yang lebih kecil dari standar deviasi yang diartikan bahwa data dalam variabel tersebut tidak berkelompok atau bervariasi. Dalam pengolahan data dengan menggunakan analisis regresi panel, dilakukan beberapa tahapan untuk mencari hubungan antara variabel independen dan dependen.

\section{Uji Hausman}

Berdasarkan hasil yang data yang telah diuji menunjukkan bahwa variabel NPF berpengaruh secara positif terhadap Return on Asset (ROA) perbankan syariah di Indonesia. Hal tersebut menunjukkan bahwa $p$-value sebesar $0.0029<0.05$. Hasil penelitian ini sesuai dengan penelitian (Sulistyo \& Indrianti, 2018) dan juga di dukung oleh penelitian oleh (Nurismalatri, 2019) Hal ini disebabkan oleh fenomena data laporan keuangan bank syariah pada waktu periode penelitian Capital Adequacy Ratio (CAR) mengalami kenaikan sedangkan Return on Asset (ROA) mengalami penurunan. semakin tinggi CAR, maka semakin baik kemampuan bank syariah dalam menanggung risiko dari setiap pembiayaan atau aktiva produktif yang berisiko. Rasio ini penting karena dengan menjaga CAR pada batas aman yaitu minimal 8 \%. Hal ini dapat diartikan untuk melindungi nasabah dan menjaga stabilitas sistem keuangan secara keseluruhan dan secara bertahap akan disesuaikan dengan kondisi perbankan di Indonesia dan perbankan internasional.

\section{Pengaruh FDR terhadap ROA Perbankan Syariah}

Berdasarkan hasil yang data yang telah diuji menunjukkan bahwa variabel FDR tidak berpengaruh secara positif terhadap Return on Asset (ROA) perbankan syariah di Indonesia. Hal tersebut menunjukkan bahwa $p$-value sebesar $0.5546>0.05$. Hasil penelitian ini sesuai dengan penelitian (Said \& Ali, 2016). Hal ini menunjukkan bahwa semakin tinggi rasio FDR perbankan syariah, semakin efektif bank syariah dalam mendistribusikan dananya. Namun keberhasilannya sangat tergantung pada kualitas pembiayaan yang disalurkan. Apabila pembiayaan yang disalurkan besar namun tidak disertai dengan rendahnya pembiayaan bermasalah (NPF) maka perbankan syariah tidak akan menghasilkan profitabilitas (Yusuf \& Surjaatmadja, 2018)

\section{Pengaruh CAR terhadap ROA Perbankan Syariah}

Berdasarkan hasil yang data yang telah di uji menunjukkan bahwa variabel CAR berpengaruh secara positif terhadap Return on Asset (ROA) perbankan syariah di Indonesia. Hal tersebut menunjukkan bahwa $p$-value sebesar $0.0003<0.05$. Hasil penelitian ini sesuai dengan penelitian (Abdillah, Hosen, \& Muhari, 2016: Farandy, Suwito, \& Dabutar, 2017). Bank yang mempunyai CAR yang lebih tinggi sangat baik karena ini mampu menanggung resiko yang timbul. Jika nilai CAR tinggi (sesuai ketentuan BI) berarti bank tersebut mampu membiayai operasi bank, keadaan yang menguntungkan bank tersebut akan memberikan kontribusi yang cukup besar bagi profitabilitas disisi lain bahwa CAR berpengaruh positif terhadap ROA, hal tersebut dikarenakan CAR sangat mempengaruhi kepercayaan masyarakat terhadap bank, dimana kepercayaan masyarakat merupakan modal dasar bagi kelangsungan lembaga keuangan ini. Tingkat CAR yang ideal akan sangat 
menguntungkan bagi bank dan dapat meningkatkan kepercayaan masyarakat sebagai pemilik dana, sehingga masyarakat akan memiliki keinginan yang lebih untuk menyimpan dananya di bank (Zulifiah \& Susilowibowo, 2014).

Berdasarkan hasil yang data yang telah diuji menunjukkan bahwa variabel BOPO berpengaruh secara positif terhadap Return on Asset (ROA) perbankan syariah di Indonesia. Hal tersebut menunjukkan bahwa $p$-value sebesar $0.0063<0.05$. Hasil penelitian ini sesuai dengan penelitian (Hazrati Havidz \& Setiawan, 2015: Amelia, 2015). Hal ini dinyatakan dalam perbankan dan industri pada umumnya terjadi hubungan negatif antara biaya operasional dan pendapatan operasional (BOPO) dengan profitabilitas. BOPO menunjukkan seberapa besar bank dapat menekan biaya operasionalnya di satu pihak, dan seberapa besar kemampuan untuk meningkatkan pendapatan operasional di pihak lain. BOPO memiliki pengaruh terhadap kinerja perbankan karena menunjukkan seberapa besar bank dapat melakukan efisiensi terhadap biaya operasional yang dikeluarkan. Semakin kecil rasio BOPO, berarti semakin efisien biaya operasional yang dikeluarkan bank yang bersangkutan sehingga kemungkinan yang lebih besar bagi bank untuk mendapatkan keuntungan yang lebih dan menunjukkan bahwa bank tidak berada dalam kondisi bermasalah.

\section{Uji Simultan}

Digunakan untuk melihat pengaruh dari keseluruhan variabel independen terhadap varabel dependen secara bersamaan. Taraf signifikansi yang digunakan adalah 0.05. Pengaruh variabel independen yaitu $\mathrm{X}_{1}=$ Non Performing Financing (NPF) $\mathrm{X}_{2}=$ Financing Deposit Ratio (FDR) $\mathrm{X}_{3}=$ Capital Adequacy ratio (CAR), $\mathrm{X}_{4}=$ biaya operasional terhadap pendapatan operasional (BOPO) terhadap variabel dependen yaitu Return on Asset (ROA). Berdasarkan hasil pengujian didapatkan nilai probabilitas $0.00<0.05$. Sehingga menunjukkan bahwa dalam penelitian ini keseluruhan variabel independen bersama-sama berpengaruh secara signifikan terhadap variabel dependen.

\section{KESIMPULAN DAN IMPLIKASI}

Berdasarkan hasil penelitian pengaruh NPF, FDR, CAR, dan BOPO terhadap profitabilitas perbankan syariah di Indonesia periode 2010-2017, dapat ditarik kesimpulan bahwa NPF, CAR, dan BOPO berpengaruh positif dan signifikan terhadap ROA perbankan syariah Indonesia, sedangkan FDR memiliki tidak memiliki pengaruh positif terhadap ROA perbankan syariah di Indonesia. Maka dari itu perbankan syariah dapat memperhatikan tingkat NPF, CAR, dan BOPO untuk meningkatkan kinerja perusahaan sehingga dapat meningkatkan profitabilitas pula. Karena variabel tersebut berpengaruh signifikan terhadap profitabiltas bank syariah. Dan diharapkan kepada investor untuk memperhatikan performance perbankan syariah dalam mengambil keputusan.

\section{DAFTAR PUSTAKA}

Abdillah, R., Hosen, M. N., \& Muhari, S. (2016). The Determinan Factor of Islamic Bank's Profitability and Liquidity in Indonesia. Knowledge Horizons-Economics, 140-147.

Almunawwaroh, M., \& Marliana, R. (2018). Pengaruh CAR, NPF, dan FDR terhadap Profitabilitas Bank Syariah di Indonesia. Jurnal Ekonomi dan Keuangan Syariah , 1-18.

Amelia, E. (2015). Financial Ratio and Its Influence to Profitability in Islamic Bank . Al-Iqtishad , 229-240.

Amzal , C. (2016). The Impact of Macroeconomic Variables on Indonesia Islamic Banks Profitability. Jurnal Ekonomi dan Bisnis , 71-86.

Artha, I., \& Mulyana, B. (2018). The Effect of Internal and External Factors of Companies on Profitability and its 
Implications on Stock Price Index of State Owned Banks. The Economics and Finance Letters, 58-71.

Broome, T., Moore, J., \& Winston. (2009). Liquidity and the Firm Size-Growth Nexus in Barbados. he Annual Review Seminar Research Department Central Bank of, 1-16.

Farandy, A. R., Suwito, D. A., \& Dabutar, L. K. (2017). Eficiency of Islamic Banks in Indonesia: Data Envelopment Analysis. International Journal of Economics, Management and Accounting , 337-354.

Farandy, A. R., Suwito, D. A., \& Dabutar, L. K. (2017). Eficiency of Islamic Banks Indonesia: Data Envelopment Analysis. International Journal of Economics, Management and Accounting 25, 337-354.

Hakiim, N., \& Rafsanjani, H. (2016). Pengaruh Internal Capital Adequency Ratio (CAR), Financing to Deposit Ratio (FDR), dan biaya Operasional Per Pendapatan Operasional (BOPO) dalam Peningkatan Profitabilitas Industri Bank Syariah di Indonesia. Jurnal Perbankan Syariah, 60-74.

Harianto , S. (2017). Rasio Keuangan dan Pengaruhnya Terhadap Profitabilitas pada Bank Pembiayaan Rakyat Syariah Indonesia . Jurnal Bisnis dan Manajemen , 41-48.

Hazrati Havidz, S. A., \& Setiawan, C. (2015). Bank Eficiency and Non Performing Financing (NPF) in the Inonesia Islamic Banks . Asian Journal of Economic Modelling , 61-79.

Husaeni, U. A., Jamil, I., \& Riadi, A. S. (2013). Analysis of the Effect Third Party Funds and Non Performing Financing toward Return on Assets of Sharia Rular Bank (BPRS) in Indonesia in the Year 2014 to June 2016. Fakultas Ekonomi dan Bisnis
Islam Universitas Suryakancana, 113.

Jatmiko, U., Srikalimah, \& Fitryanto, D. (2017). Effect of Capital Adequacy and non Performing Financing on Return on Asset in PT Bank Rakyat Indonesia (BRI) Syariah Period 2012-2016. International Journal of Social Science And Business, 222-228.

Kusa, V. O., \& Berhanu, G. (2013). Determinants of Financial Performance of Commercial Banks in Kenya. International Journal of Economics and Financial Issues , 237525.

Mawadah, N. (2015). Factors Affecting Profitability of Bank Syariah. Economy, 241-256.

Nahar, F. H., \& Prawoto, N. (2017). Bank's Profitability in Indonesia: Case Study of Islamic Banks Period 2008-2012. Jurnal Ekonomi \& Studi Pembangunan , 164-172.

Nurismalatri. (2019). Shariah Banks Performance in Indonesia: A panel Model Aproach. Jurnal Sekuritas , 4554.

OJK. (2018). Statistik Perbankan Syariah. Jakarta: Otoritas Jasa Keuangan .

Purnamasari, G. Y., \& Ariyanto, D. (2016). Analisis Perbandingan Kinerja Keuangan Bank Konvensional dan Bank Syariah Periode 2010-2014. EJurnal Akuntansi , 82-110.

Riadi, S. (2018). The effect of Third Parties Fund, Non Performing Loan, Capital Adequacy Ratio, Loan to Deposit Ratio, Return On Assets, Net Interest Margin and Operating Expenses Operating Income on Lending (Study in Regional Development Banks in Indonesia) . Proceedings of the International Conference on Industrial Engineering and Operations Management , 10161026. 
Rosiana , D., \& Triaryati, N. (2016). Studi Komaparatif Kinerja Keuangan Pada Bank Konvensional dan Bank Syariah di Indonesia. E-Jurnal Manajemen Unud, 956-984.

Said, M., \& Ali, H. (2016). An analysis on the factors affecting profitability level of Sharia banking in Indonesia. Banks and Bank Systems , 28-36.

Said, M., \& Ali, H. (2016). An analysis on the factors affecting profitability level of Sharia banking in Indonesia. Banks and Bank Systems, 28-36.

Sitompul , S., \& Nasution, S. K. (2019). The Effect of Car, BOPO, NPF, and FDR on Profitability of Sharia Commercial Banks in Indonesia. Budapest International Research and Critics Institute-Journal (BIRCI-Journal) , 234-238.

Sriyana, J. (2015). Islamic Bank's Profitability Amid The Competitive Financing in Indonesia . IJABER, 1695-1710.

Suartini, S., Sulistyo, H., \& Indrianti, W. (2018). The Effect of on Performing Financing, Financing to Deposit Ratio and Operating Expense to Operating Income Ratio (BOPO) to Profitability. Afebi Economic and Finance Review , 69-83.

Suhartatik, N., \& Kusumaningtias. (2013). Determinants of Financing to Deposit Ratio of Islamic Banking in Indonesia. Journal of Management Department, 1-11.

Sukamana, R., \& Febriyanti, N. (2016). Islaimic Bank vs Conventional Banks in Indonesia: An Analysis on Financial Performances . Jurnal Pengurusan , 81-90.

Sulistyo, H., \& Indrianti, W. (2018). The Effect of on Non Performing Finance, Financing to Deposit Ratio and Operating Expense to Operating income Ratio (BOPO) to Profitability
(Case Study in Bank of Sharia Listed in Indonesia Stock Exchange Period 2014-2016). AFEBI Economic and Finance Review (AEFR), 69-83.

Syaichu, \& Wibowo. (2013). Analisis Pnegaruh Suku Bunga, Inflasi, CAR, BOPO, NPF terhadap Profitabilitas Bank Syariah. Journal Accounting, 110.

Wahyuningsih , Oemar, \& Suprijanto. (2015). Pengaruh car, NPF, FDR, BOPO, DAN GWM terhadap Laba Pusahaan (ROA) pada Bank Umum Syariah di Indonesia . Journal of Accounting , 9-17.

Wardana , \& Widyarti. (2015). Analisis Pengaruh CAR, FDR, NPF, BOPO, dan Size terhadap Profitabilitas pada Bank Umum Syariah di Indonesia. Journal of Management, 1-12.

Wibowo, E. S. (2013). Analisis Pengaruh Suku Bunga, Inflasi, CAR, BOPO, dan NPF terhadap Profitabilitas Bank Syariah . Diponegoro Journal of Accounting, 1-10.

Winarso, E., \& Salim, I. A. (2017). The Influence of Risk Management to the Return on Asset (ROA) Banking Sector (Case Study of Bank in Indonesia Listed in Indonesia Stock Exchange). Advances in Economics and Business , 382-393.

Yasin, A. (2018). Analisis Faktor-Faktor Yang Mempengaruhi Non Performing Financing (Npf) Di Industri Bank Pembiayaan Rakyat (Bpr) Syariah Di Indonesia. Akrual Jurnal Akuntansi, 205-225.

Yusuf, M., \& Surjaatmadja, S. (2018). Analysis of Financial Performance on Profitability with Non Performance Financing as Variable Moderation (Study at Sharia Commercial Bank in Indonesia Period 2012-2016). International Journal of Economics and Financial Issues , 126-132. 
Yusuf, M., \& Surjaatmadja, S. (2018).

Eduquancy Ratio (CAR), Non Analysis of Financial Performance on Profitability with Non Performance Financing as Variable Moderation (Study at Sharia Commercial Bank in Indonesia Period 2012-2016) . International Journal of Economics and Financial Issues, 126-132.

Performing Finance (NPF), Biaya Operasional dan Pendapatan Operasional (BOPO) terhadap Profitabilitas Bank Umum Syariah Periode 2008-2012. Jurnal Ilmu Manajemen, 759-770.

Zulifiah, F., \& Susilowibowo, J. (2014). Pengaruh Inflasi, BI Rate, Capital 